(185)

\title{
Isolation of Associated Fungal Species in Aquilaria and Gyrinops Species of Family Thymelaeaceae
}

\author{
Vidurangi A.N.G.C.K. ${ }^{1,2 *}$, Subasinghe S.M.C.U.P. ${ }^{1}$, Fernando K.M.E.P. ${ }^{1}$ \\ ${ }^{1}$ Department of Forestry and Environmental Science, University of Sri Jayewardenepura, Sri Lanka \\ ${ }^{2}$ Sadaharitha Plantations Limited, 6A, Alfred Place, Colombo 03, Sri Lanka \\ ${ }^{3}$ Department of Botany, University of Sri Jayewardenepura, Sri Lanka \\ *angckvidurangi@gmail.com
}

\begin{abstract}
Certain tree species of Aquilaria and Gyrinops of family Thymelaeaceae are capable of producing a valuable resin called agarwood as a result of a self-defense mechanism to protect the internal tissue damage caused by pathogenic microorganisms entering via wounds occurred due to natural or artificial causes. The aromatic properties of agarwood oil are extraordinary high and therefore it is extensively used for incense, perfume and for traditional medicine in different parts of the world. Among the microorganisms which are capable of causing agarwood formation inducement, fungal species are believed to be the most influential agents. The ability of agarwood production in Gyrinops walla, believed to be endemic to Sri Lanka was recently identified. Due to the legal constraints of exporting agarwood and other products extracted from G. walla, Aquilaria crassna was introduced to the country as a high income plantation crop by private sector companies. However, studies were not conducted to identify the associated fungi in these species when grown under the climatic and geological conditions of Sri Lanka, which could be potential inocula for producing agarwood in artificial manner. Therefore the present study attempted to identify the associated fungal species in various parts of G. walla and A. crassna grown in the wet zone in Sri Lanka. For this reason, leaves, un-infected normal stem tissues and agarwood formed stem tissues were extracted from G. walla and A. crassna trees growing in Neboda and Ingiriya region respectively by non-destructive sampling. Those tissues were surface sterilised and separately grown in Potato Dextrose Agar at room temperature for 7 days in the laboratory. The morphological and genetic characteristics were then used for the identification of different fungal species. Trichoderma harzianum, Botryosphaeria laricina, Aspergillus terreus, A. sojae, A. niger, Fusarium sp, one unidentified Botryosphaeria sp and Sarcinomyces sp were identified in the agarwood resinous tissues extracted from G. walla. B. laricina, A. terreus, one unidentified Botryosphaeria sp and $F$. equiseti were identified from non-resinous stem tissue samples while $T$. harzianum, Colletotrichum gloeosporioide sand A. terreus were identified from the leaves of $G$. walla. B. laricina and one unidentified Aspergillus sp were identified from resinous tissue samples of $A$. crassna while B. laricina and Diaparthe amygdale were identified from non-resinous tissues and leaf samples respectively. The tests are currently underway to identify the most influential fungal species among the above to form agarwood in artificial manner.
\end{abstract}

Keywords: Gyrinops walla, Aquilaria, Associated fungi, Agarwood, Fungal species

Acknowledgement: Sadaharitha Plantations Limited and the Centre for Forestry and Environment, University of Sri Jayewardenepura.

Proceedings of the $22^{\text {nd }}$ International Forestry and Environment Symposium 2017 of the Department of Forestry and Environmental Science, University of Sri Jayewardenepura, Sri Lanka 